\title{
Observations on the Glacial History of the Avalon Peninsula*
}

R.J. ROGERSON and C.M. TUCKER

Geography Department, Memorial University, st. John's, Nfld.

\section{Introduction}

Substantial work on the surficial geology of the Avalon Peninsula was completed by Henderson in 1959 with the publication of a surficial geology of the St. John's map sheet (G.S.C. map 35 - 1959, Scale 1:250,000). This work summarily describes the following sequence: (1) Complete glaciation of the central and northern parts of the Avalon Peninsula; (2) An ice dome centered over the head of St. Mary's Bay during the Wisconsin maximum independent of the ice dome covering the rest of Newfoundland; (3) Rapid late-glacial recession over the St. John's and Bay de Verde Peninsulas with a shrinking ice cap centered over the head of St. Mary's Bay. At the northern ice margin recessional moraines in shallow lakes dammed up between the ice front and the northward drainage divide; (4) Scattered evidence of post-glacial emergence with a zero isobase on the elevation of post-glacial shorelines running southwestward down Trinity Bay and somewhere to the west of St. Mary's Bay.

Several more recent works have re-expressed or added to this information. Prest (1969) has drawn tentative isochrones of the retreat of Wisconsin ice, obviously based on Henderson's work, for he shows the last ice on the Avalon Peninsula situated over the head of St. Mary's Bay. Brueckner (1969) observed that a great number of bench remnants, apparently wave cut, exist a few metres above sea level in several locations, and described a bedded beach deposit $6 \mathrm{~m}$ above sea level (asl) at Horse Cove, Conception Bay (Fig. 1).

This report details the results of a recent examination of the moraines of the central Avalon Peninsula, and adds to the scattered evidence of raised marine landforms in the southeastern part of the peninsula.

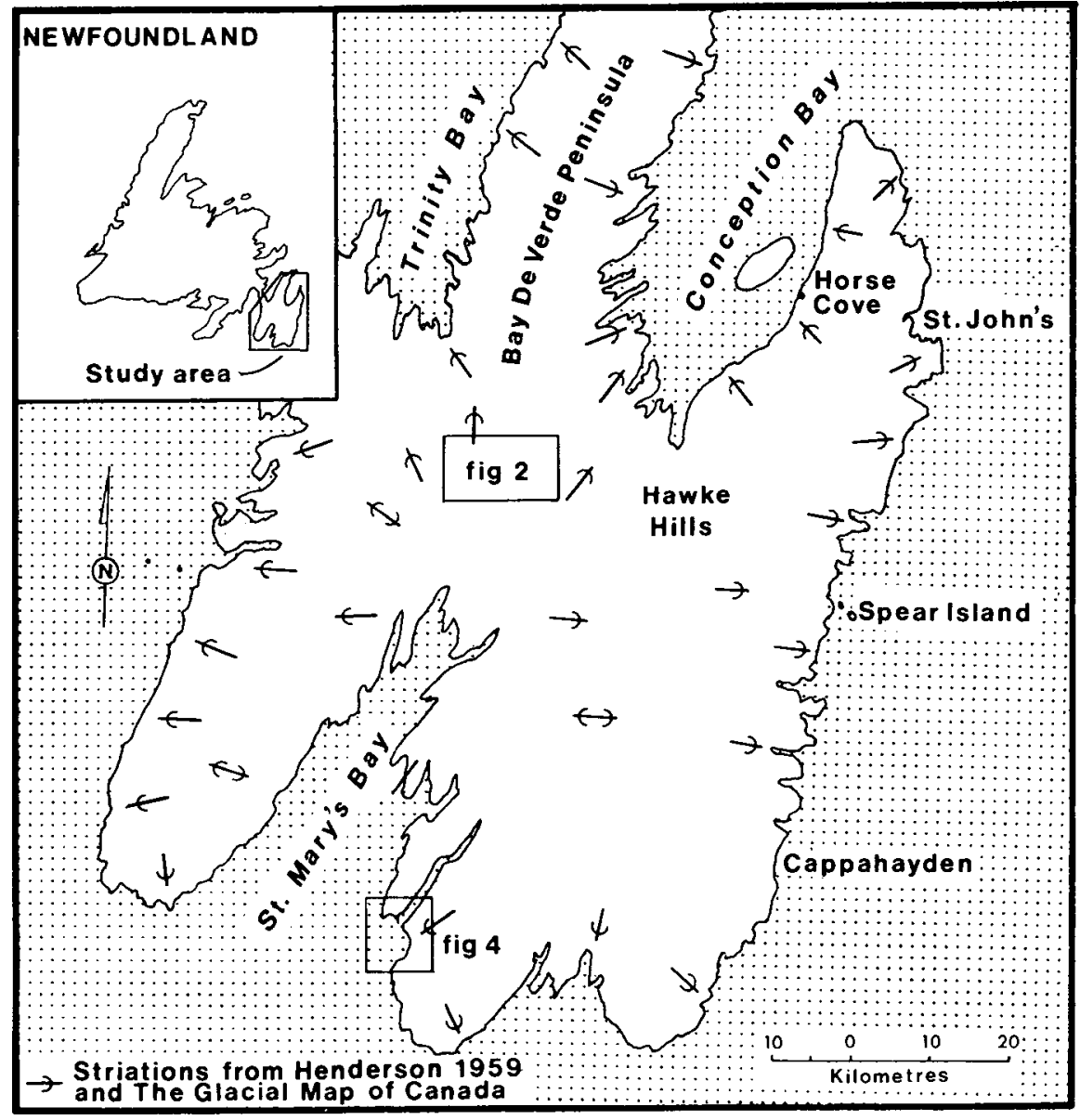

Figure 1 - The Avalon Peninsula: Location map and glac. ial striations. 


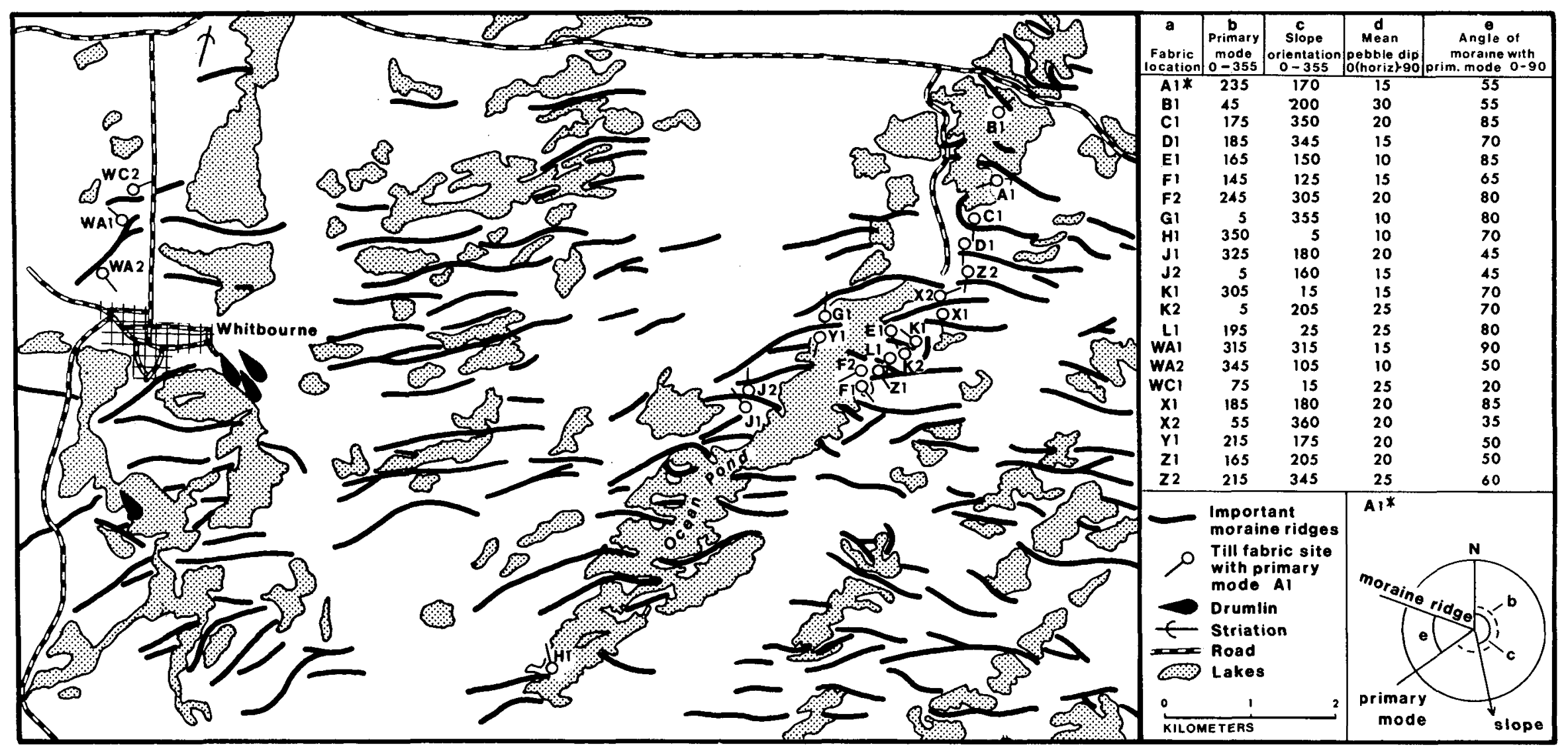

Figure 2 - Central Avalon moraines and till fabric analysis results. 


\section{The Central Avalon Moraines}

An area of the central Avalon about $20 \mathrm{~km}^{2}$, east of Whitbourne, is noted for the extensive cover of moraine formed into sub-parallel ridges trending in general from west to east (Fig. 2).

Orientation of the moraine ridges is normal to the general direction of ice flow, indicated by local striations (Henderson 1959). Individually the moraines undulate and branch, although a number of ridges are continuous for a distance approaching 2,500 $\mathrm{m}$. Near whitbourne, the ridges pass into a broken zone of drumlins. The ridges vary in height from $10 \mathrm{~m}$ to $30 \mathrm{~m}$ (Fig. 3) and the average distance between them varies from $200 \mathrm{~m}$ to $400 \mathrm{~m}$. While most of the ridges are asymetrical in cross-section there is no consistent orientation of asymmetry. In the hollows between the moraines evidence of proglacial lakes is completely lacking, and while from their morphology it is not totally clear whether the moraines are analogous to cross-valley moraines as described by Andrews (1963), or ribbed moraine as described by Cowan (1968) and Prest (1968), the latter interpretation is certainly favoured. Cross-valley moraines, which are recessional ice-frontal deposits formed in transient proglacial lakes, would confirm that the head of St. Mary's Bay was the centre of a last shrinking ice cap. Ribbed moraine however is a subglacial deposit, related to and sometimes found associated with drumlins, but oriented transverse to flow direction. Ribbed moraine therefore represents an earlier period when ice covered much, or all, of the Avalon Peninsula and dispersed radially outwards from the centre of the ice sheet, situated presumably over the head of st. Mary's Bay.

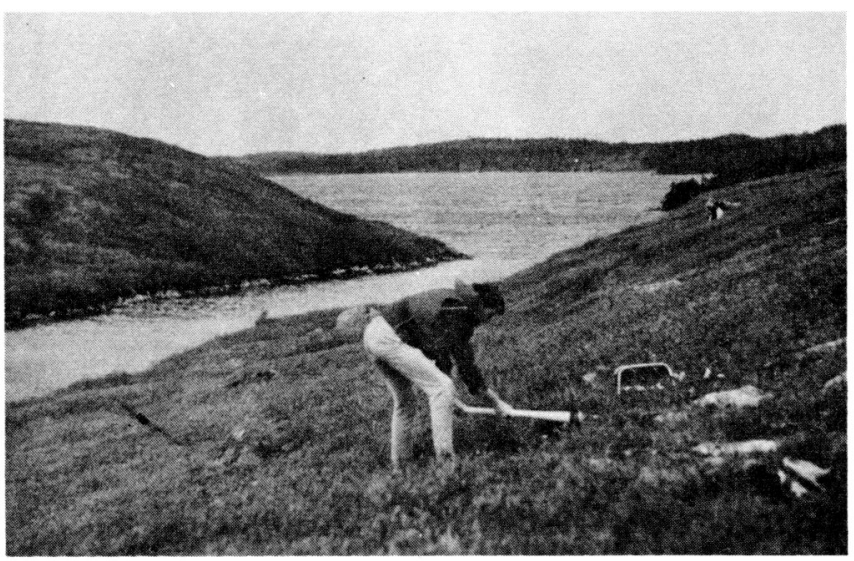

Figure 3 - Site $\mathrm{Zl}$ on the south-facing slope of a moraine ridge. Here the distance between ridges is less than average and the intervening hollow drowned by the water on Ocean Pond.

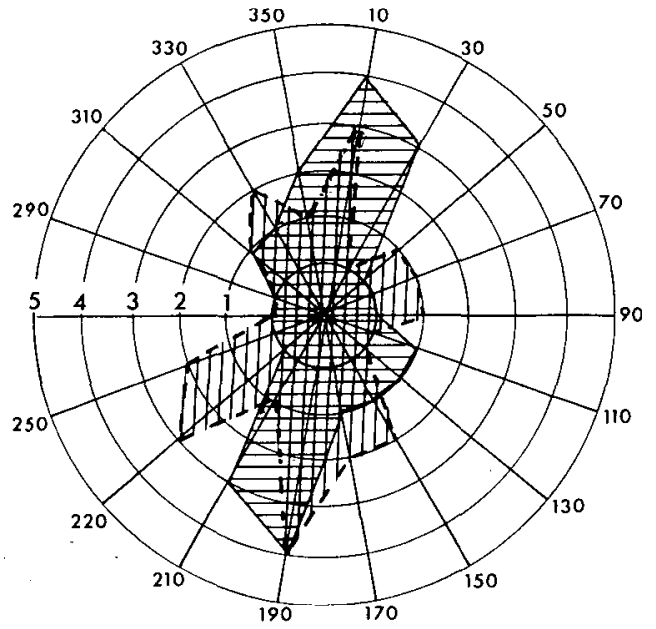

Orientation of primary modes in $20^{\circ}$ classes 1$]$ [III Orientation of slopes in $20^{\circ}$ classes

Figure 4 - Cumulative orientations of primary modes (Fig. 2, column b), and moraine slope (Fig. 2, column c).

Further differentiation between cross-valley and ribbed moraine may be accomplished by conducting three-dimensional till fabric analyses since cross-valley moraines display marked upglacier imbrication of clasts. In the case of ribbed moraine, most pebbles dip sub-parallel to the slope of the moraine flank. In addition, only where cross-valley moraine is distinctly lobate or in sections trending sub-parallel to the direction of glacier flow does the primary mode or pebble orientation lie other than normal to the crest orientation of the moraine (Price, 1970).

Till fabrics at 22 localities in the Ocean Pond and Whitborne areas have significant primary modes at the $95 \%$ level of probability according to Harris' MSOC Graph (Harris, 1969). Orientations of the primary modes vary considerably (Fig. 2) although they lie generally along a north-south line (Fig. 4). The primary mode is seldom perfectly normal to the crest orientation of the moraine. In all but three cases the dips of oriented pebbles accord more with the slope of the moraine than a consistent up-glacier pattern (Fig. 4).

These results indicate that the area is one of sub-glacially formed ribbed moraine probably deposited during a period of active dispersal preceding the ultimate recession of Avalon Ice. These moraines should not be confused with ice-frontal recessional moraine and therefore do not indicate that the last ice survived over the head of St. Mary's Bay. It would be appropriate in proposing this to also suggest an alternative last ice centre for the Avalon. An abundance of stagnant ice and melt-water features in the northward sloping valleys of the Hawke Hills (Fig. 5) implies very strongly that ice remained there long after it had melted from the adjacent plateaux and lowlands. This and other areas of high relief are perhaps more logical sites of residual ice stagnation. 


\section{Raised Marine Landforms}

A number of horizontal or near-horizontal levels on glacial till occur on the islands or extremities of Peninsulas between Tors Cove and Cappahayden (Fig. 1). Lying from 5 to $15 \mathrm{~m}$ asl, these features are not to be confused with pre-classical wisconsin eroded rock benches described by Henderson along the southern shore.

\section{Spear Island:}

A distinctive surface deposit of well-rounded beach cobbles exists $11 \mathrm{~m}$ asl on Spear Island, $40 \mathrm{~km}$ south of st. John's. This deposit rests on an easily distinguished eroded surface in glacial till, 10 to $15 \mathrm{~m}$ asl (Fig. 6) and is partly overgrown by a thin turf cover (Fig. 7). Where the cobbles are bare of turf they are covered by epipetric lichens on their upper surfaces (Fig. 8) and appear totally undisturbed by modern wind or wave action. The adjacent Avalon shoreline contains no raised beach or similar evidence of post-glacial emergence.

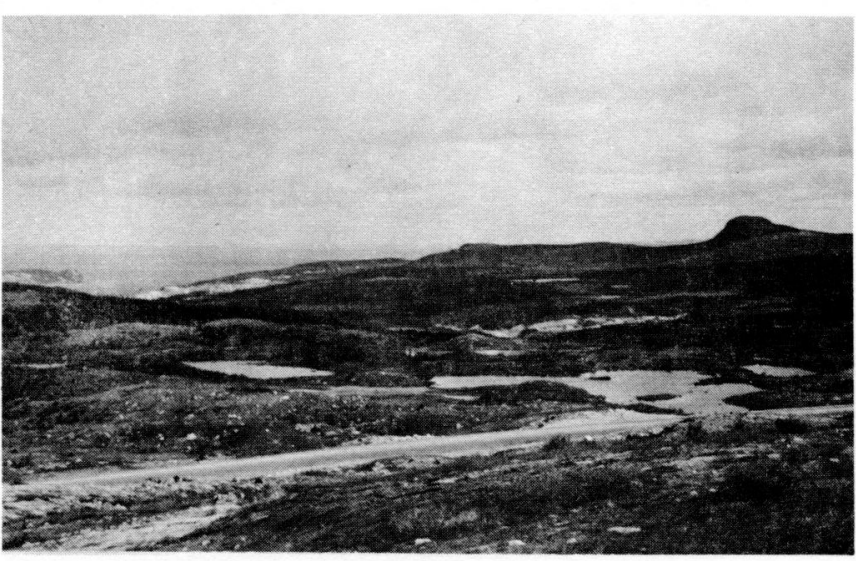

Figure 5 - Dead-ice terrain in the Hawke Hills near the TransCanada Highway. The heavy mantle of pitted moraine is backed by a profusion of melt-water channels.

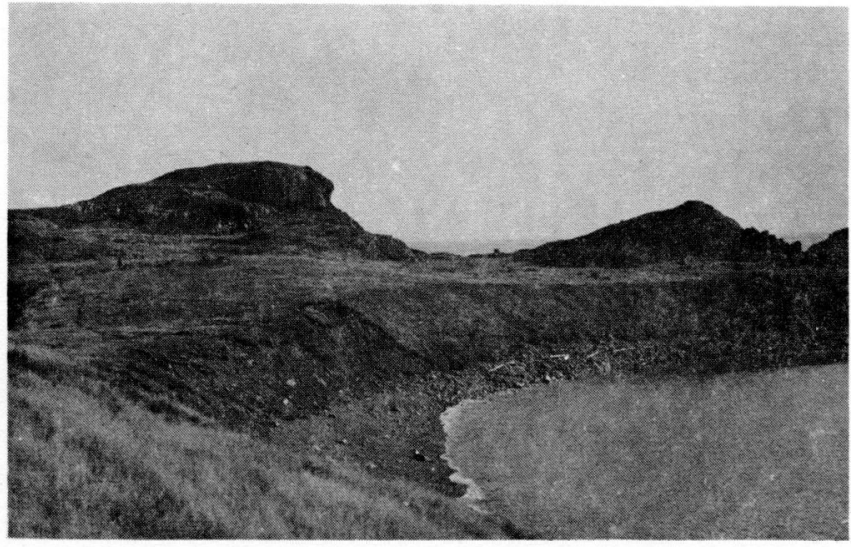

Figure 6 - A distinct erosion surface in glacial stil; 10 to $15 \mathrm{~m}$ asI Spear Island, Avalon Peninsula.

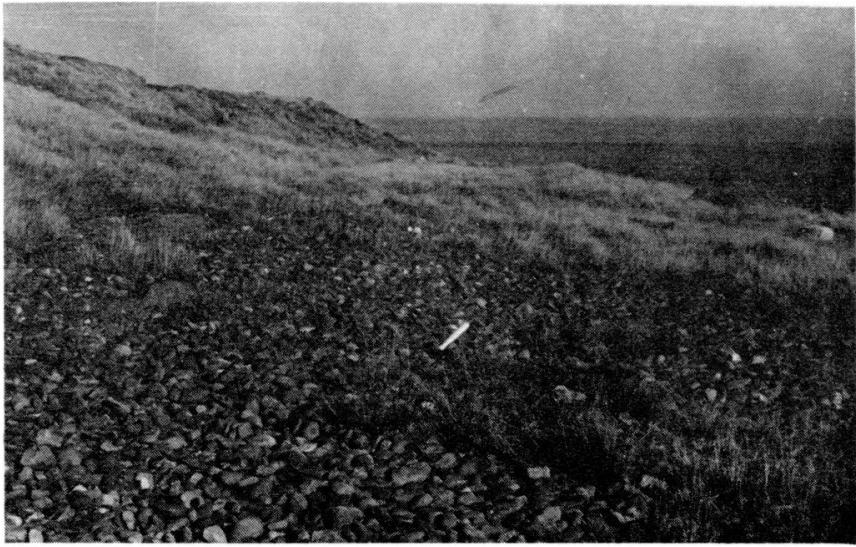

Figure 7 - Well-rounda d beach cobbles partly overgrown by furf, 11 m asl, Spear |sland, Avalon Peninsula.

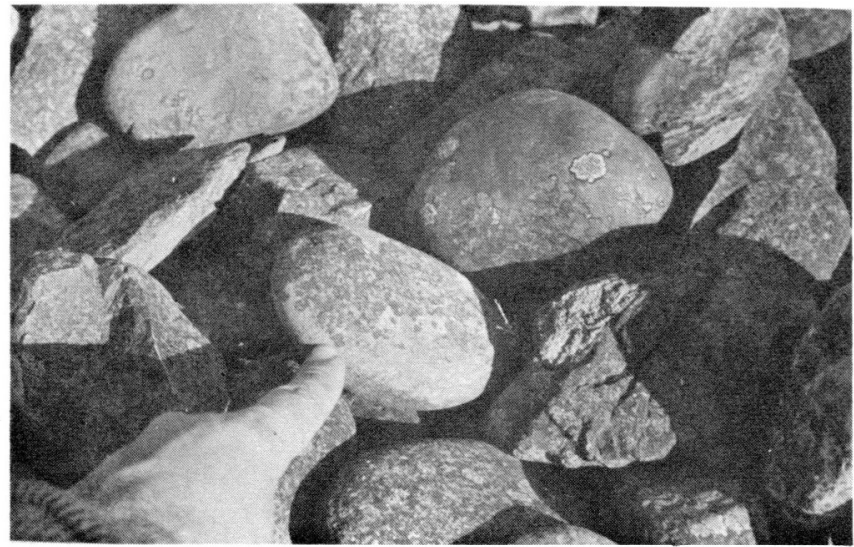

Figure 8 - Epipetric lichens on the upper surfaces of raised beach cobbles. Spear Island, Avalon Peninsula. 


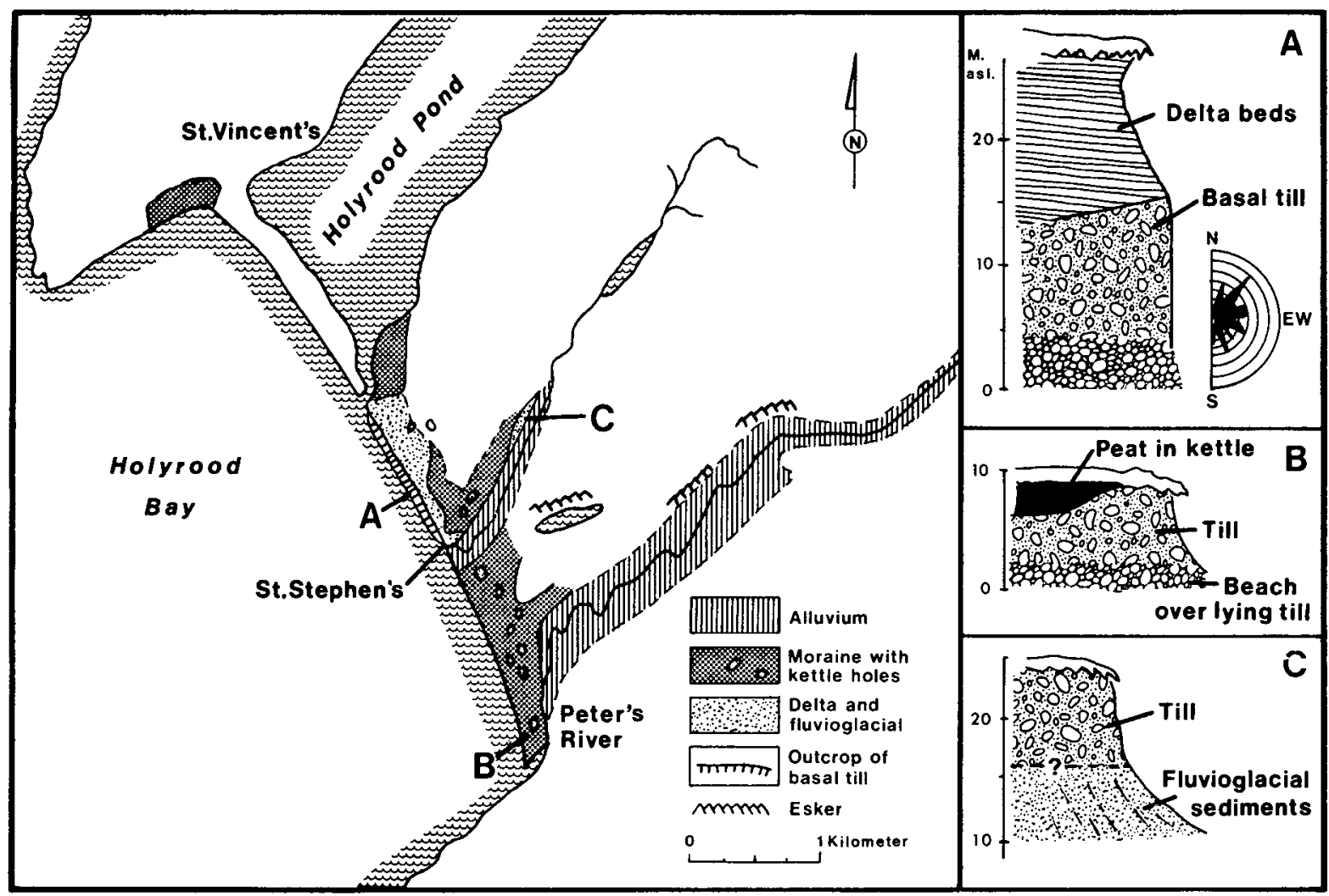

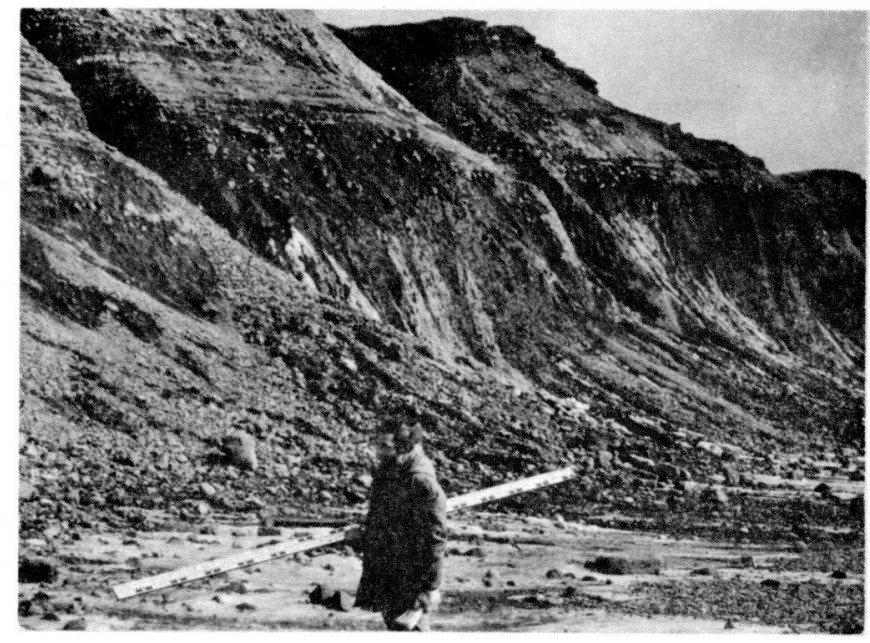

Figure 10 - Section A. Holyrood Bay. Delta gravel and sand beds overlying a massiva layer of compacted basol till.

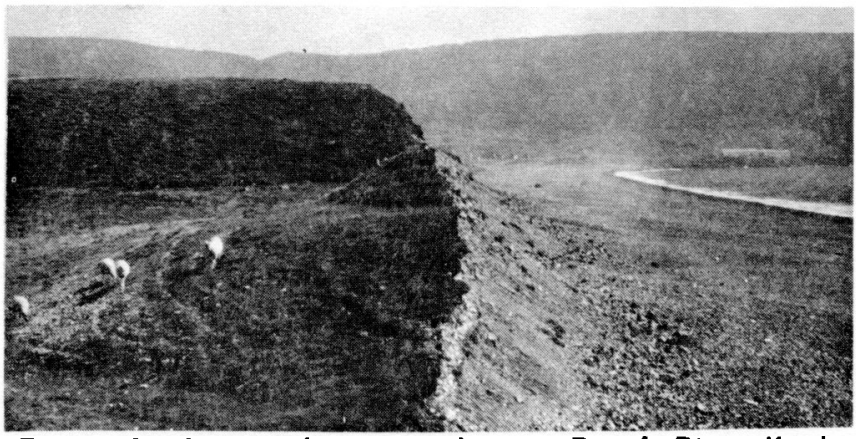

Figure 12 - Section of moraine ridge near Peter's River. Kettle holes are numerous in the moraine and many contain some thickness of peat overlying silty bottom beds presumably accumulated in shallow ponds.
Figure 9 - Holyrood Bay: Location of glacial and fluvioglacial features with repres? ntotive cross-sections.

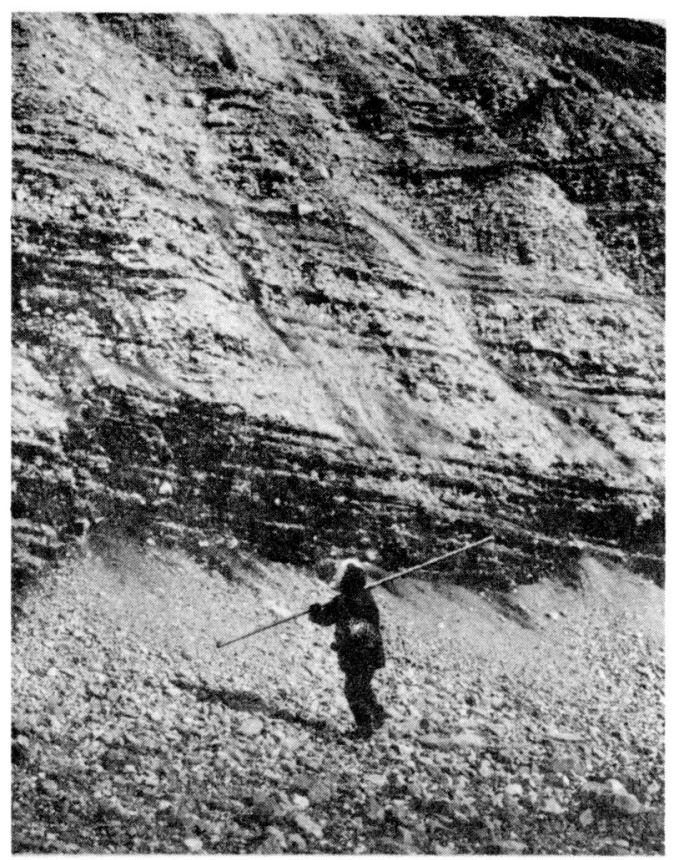

Figure 11 - Delta beds extending from 5 to almost 25 - asl, north of s-ction A, H-lyr-ad Bay. 


\section{Holyrood Bay:}

At Holyrood Bay (Fig. 9) even more spectacular evidence of post-glacial marine overlap survives. At Section A (Fig. 10) and nearby (Fig. 11), delta foreset and topset bedding extends up to $25 \mathrm{~m}$ asl, and overlies a layer of compacted till. Towards Peter's River at Section B, the delta deposit appears to be interrupted by a number of moraine ridges (Fig. 12) backed by remnants of an esker system. Inland, at section $C$ till overlies fluvioglacial deposits which may be continuous with the delta in Section A. Towards St. Vincent's the delta appears to be terminated abruptly at the mouth of Holyrood Pond. Grain size analysis of the sediment finer than -3 phi indicates obvious differences between the delta material and the underlying till since clay-sized particles present in the till are not present in the delta (Fig. 13). Fabric analysis of the compacted basal till reveals a weak orientation of clasts approximately normal to the coastline (Fig. 9). No shells or microfauna have yet been found in the deposit.

Complex post-glacial terraces along the valley of Peter's River have not yet been carefully analyzed neither have stratigraphical colour variations in drift west of st. Vincent's. These are the subject of continuing research.

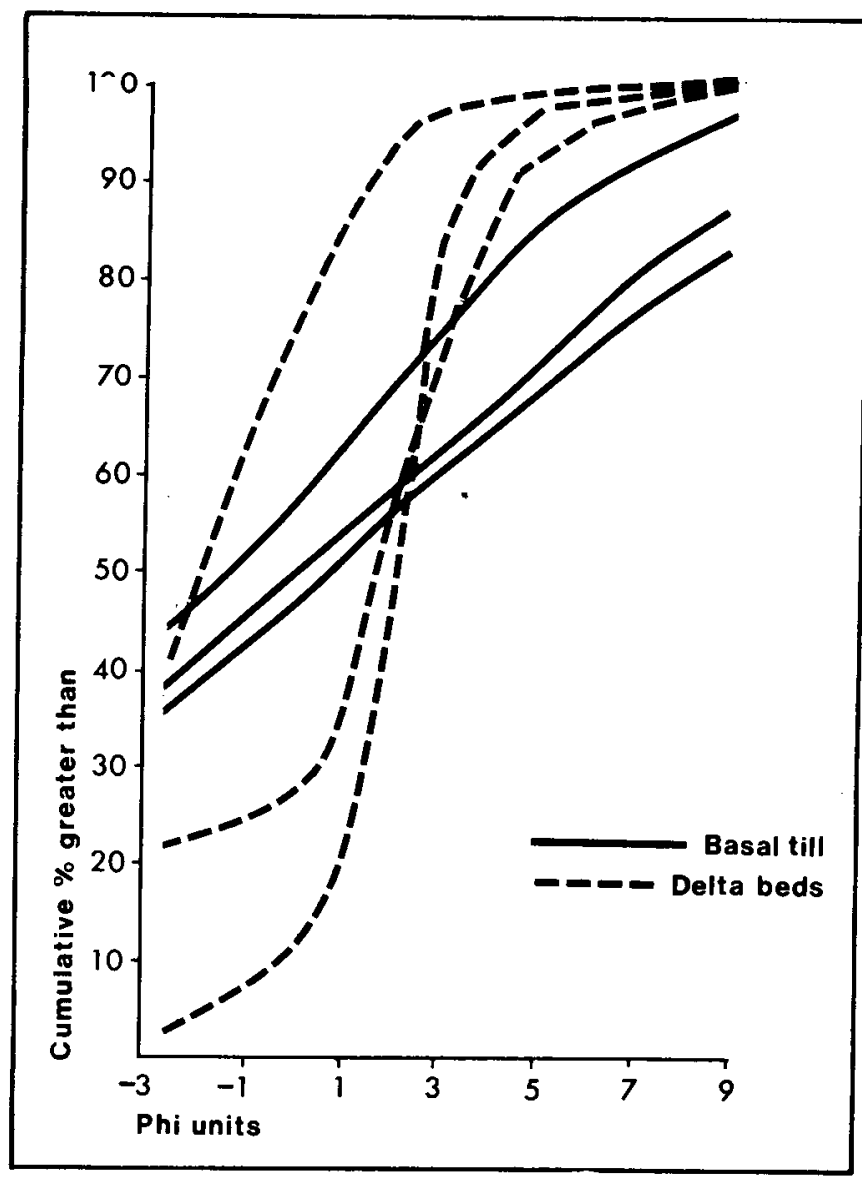

Figure 13 - Cumulative curves of grain size distribution of Holyrood Bay sediments.

Coastal Deglaciation

The deglacial events suggested by the features at Spear Island and Peter's River are briefly summarized:

Although ice may have filled all the bays of the Avalon during the Wisconsin maximum (Henderson, 1959), and even extended half way across the continental shelf (King, 1969; Slatt, Memorial University of Newfoundland, personal communication), at some later stage the bays and continental shelf must have been virtually free of ice while the land remained ice-covered. This is clear since most glacial striations found around the Avalon are simply normal to the trend of the coastline (Fig. I) and most likely an ice edge. The discontinuity of raised beaches provides further proof. A number of islands and peninsulas probably extended beyond this ice edge and were therefore deglaciated earlier than most of the Avalon shoreline, with post-glacial rebound appearing early enough for it to exceed a contemporaneous sea level rise. By the time most of the coastline was deglaciated, remaining post-glacial uplift must have been less than the subsequent sea level rise, resulting in the drowning of post-glacial shorelines formed then or since that time. 
At Holyrood Bay early deglaciation was accompanied by a period of delta deposition contemporaneous with, or followed by, a readvance of ice down the valley of Peter's River, building the terminal moraine to the south of, and possibly overlying the delta. Readvance may also have occurred down the valley of Holyrood Pond, truncating the northwest part of the delta.

Acknowledgements

The authors are very grateful to Dr. Roger Slatt, Geology Department, Memorial University of Newfoundland, for his field advice and for grain-size analyses of the Holyrood Bay samples.

Dr. Joyce Macpherson kindly read the manuscript and offered useful suggestions. Mr. Gilbert Learning drew the figures.

\section{References cited}

ANDREWS, J.T., 1963, Cross-valley moraines of the Rimrock and Isortoq River Valleys, Baffin Island, N.W.T., A Descriptive Analysis. Geog. Bull. No. 19, pp. 49-77.

BRUECKNER, W.D., 1969, Post-glacial geomorphic features in Newfoundland, Eastern Canada. Ecologae Geologicae Helvetiae Vol. 62, No. 2, pp. 417-441.

COWAN, W.R., 1968, Ribbed moraine: Till-fabric analysis and origin. Canadian Journal of Earth Sciences, Vol. 5, No. 5, pp. 1145-1159.

HARRIS, S.A., 1969, The meaning of till fabrics. In: Nelson \& Chambers (Eds.) "Geomorphology", Methuen, pp. 143-164.

HENDERSON, E.P., 1959, Surficial geology: St. John's, Newfoundland Map 35-1959, Geological Survey of Canada.

KING, L.H., 1969, Submarine end moraines and associated deposits on the Scotian Shelf. Geol. Soc. Am. Bull., Vol. 80, pp. 83-96.

PREST, V.K., 1968, Nomenclature of moraines and ice-flow features as applied to the Glacial Map of Canada. Paper 67-57, Geological Survey of Canada.

1969, Retreat of Wisconsin and Recent ice in North America. Map 1257A, Geological Survey of Canada.

PRICE, R.J., 1970, Moraines at Fjallsjökull, Iceland. Arctic and Alpine Research, Vol. 2, No. 1, pp. $27-42$. 